\title{
Pluralisme Dalam Pandangan Pemuda Lintas Agama di Surabaya
}

\author{
M Thoriqul Huda, Isna Alfi Maghfiroh \\ Institut Pesantren KH Abdul Chalim Mojokerto, UIN Sunan Ampel Surabaya \\ huda90.ikhac@gmail.com, Isnarisky97@gmail.com
}

\begin{abstract}
Riwayat Jurnal
Artikel diterima: 28 Desember 2018

Artikel direvisi: 24 Juni 2019

Artikel disetujui: 24 Juni 2019

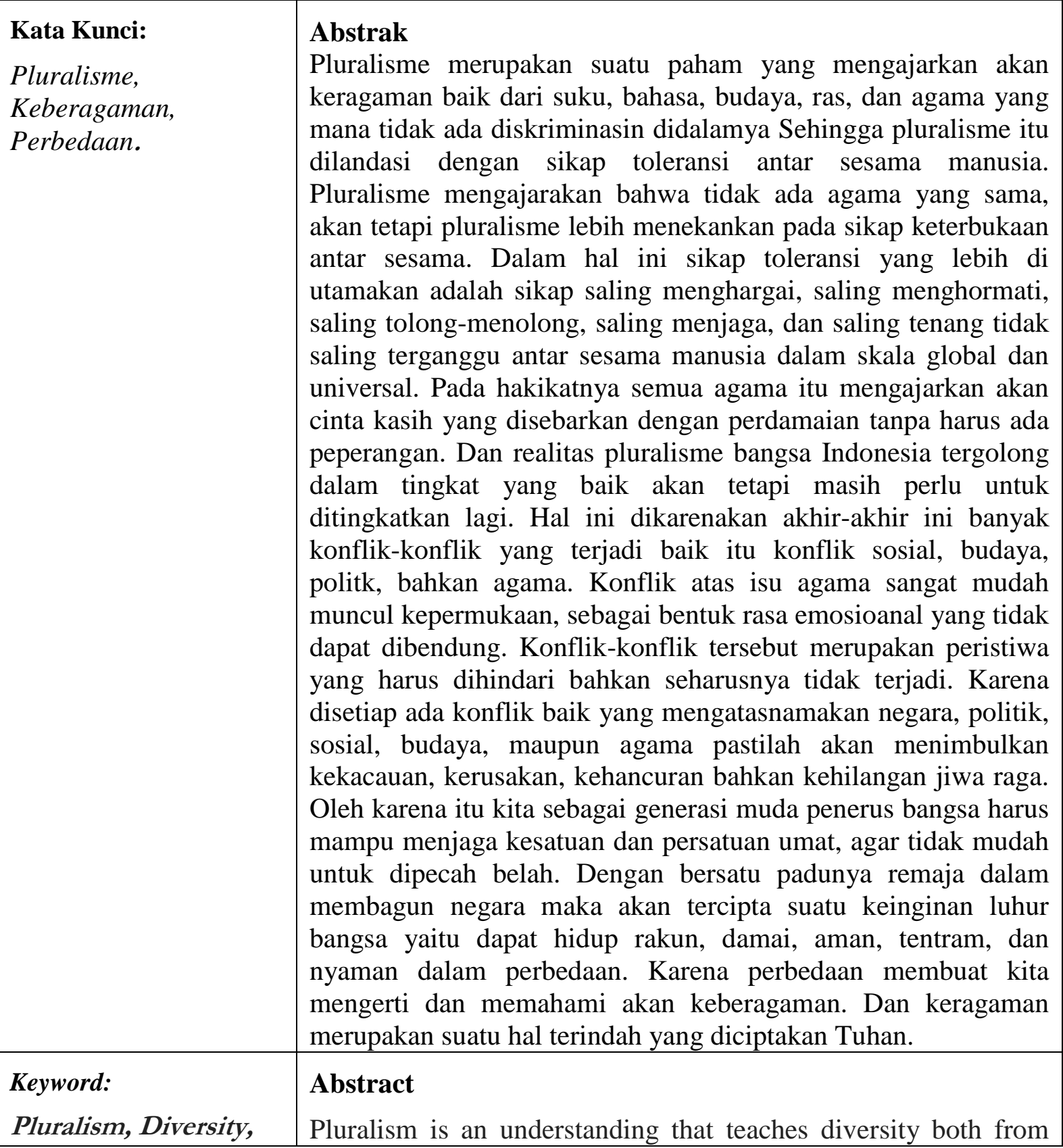

Satya Widya: Jurnal Studi Agama

Volume 2 Nomor 1 Juni 2019 


\begin{tabular}{|l|l|}
\hline Difference. & ethnicity, language, culture, race, and religion which does not \\
discriminate in it. So that pluralism is based on an attitude of \\
tolerance among fellow humans. Pluralism teaches that there is \\
no religion, but pluralism emphasizes openness among others. In \\
this case tolerance which is more prioritized is mutual respect, \\
mutual respect, mutual help, mutual care, and mutual calm are \\
not interfered with among humans on a global and universal \\
scale. In essence all religions teach about love that is spread by \\
peace without having to have war. And the reality of Indonesian \\
pluralism is classified as a good level but still needs to be \\
improved. This is because lately there have been many conflicts \\
that have occurred both social, cultural, political, and even \\
religious conflicts. Conflict over the issue of religion is very easy \\
to appear on the surface, as a form of emotional feeling that \\
cannot be stopped. These conflicts are events that must be \\
avoided and should not even occur. Because every conflict in the \\
name of the state, politics, social, culture, or religion will \\
certainly cause chaos, damage, destruction and even loss of body \\
and soul. Therefore we as the young generation of the nation's \\
successors must be able to maintain the unity and unity of the \\
people, so that it is not easy to be divided. By unifying the \\
adolescents in developing the country, a noble desire will be \\
created, namely to be able to live raccoon, peace, security, peace \\
and comfort in diversity. Because differences make us \\
understand and understand diversity. And diversity is the most \\
beautiful thing God created.
\end{tabular}

\section{Pendahuluan}

Indonesia merupakan negara yang berideologi Pancasila dan berasas Bhineka Tunggak Ika, bermakna walaupun berbeda-beda tetapi tetap satu jua. Yang mana Indonesia mengakui bahwa terdapat enam agama resmi di pakai dan dijalankan dalam kehidupan sehari-hari. Agama-agama tersebut antara lain yaitu: Islam, Khatolik, Protestan, Hindu, Buddha, dan Konghucu. Indonesia juga terdiri dari banyak suku bangsa, bahasa, budaya, etnis, dan ras. Indonesia dipandang dunia sebagai negara pluralitas, hal ini berdasarkan keragaman yang mewarnainya baik dari segi budaya, bahasa, suku, maupun agama. Hildred Geertz (tokoh Antropologi dari Amerika) mendefinisikan keragaman masyarakat Indonesia, sebagaimana di jelaskan dalam jurnal Al-Afkar yang di tulis oleh Asep Lukman Hamid sebagai berikut: keragaman di Indonesia terdiri dari 300 lebih suku yang mendiaminya, sukusuku tersebut memiliki indentitas kebudayaannya masing-masing. Juga terdapat 250 lebih bahasa daerah yang digunakan, serta terdapat banyak agama-agama didalamnya yaitu agama resmi yang di tetapkan pemerintah dan agama yang merupakan aliran kepercayaan dari setiap suku di Indonesia (Asep Lukman Hamid, 2018: 113). Sedangkan persentasi jumlah umat 
beragama di Indonesia oleh Badan Pusat Statistik melalui sensus penduduk pada tahun 2010, menyebutkan bahwa jumlah umat beragama paling banyak adalah Islam dengan $87,18 \%$, kemudian di susul oleh Kristen sebesar 6, 96\%, diposisi ketiga ditempati oleh Katholik 2, 90\%, setelah itu Hindu dengan 1,69\%, dan Buddha sebesar 0,75\%, kemudian penganut keyakinan lain sebesar 0, 13\%, dan diposisi terakhir di tempati oleh Konghucu dengan 0,05\% (Sonie Setiawan, Listyaningsi, 2018: 137). Persentasi tersebut akan terus meningkat sesuai pertumbuhan penduduk indonesia.

Dari keberagaman tersebut munculah suatu sikap toleransi antar sesama umat beragama untuk dapat hidup rukun berdampingan tanpa adanya suatu perselisihan. Tujuan utama dari toleransi yaitu menciptakan kehidupan yang harmonis, rukun, dan damai antar umat beragama. Tujuan tersebut di pengaruhi oleh adanya peristiwa-peristiwa yang menyulut terpecahnya persatuan bangsa Indonesia. Keberdaan agama-agama yang beragam tidak dapat di elakkan dan turut andil dalam menyumbang pluralitas (kemajemukan) bangsa Indonesia (Djohan Effendi, 1985: 169). Kemajemukan tersebut di imbangi dengan adanya sikap toleransi antar umat beragama, sehingga akan tercipta suatu perdamaian tanpa adanya permusuhan. Pada hakikatnya semua agama mengajarakan serta membawa perdamaian dan kasih sayang. Tidak ada agama di dunia ini yang mengajarkan permusuhan. Permusuhan itu timbul dikarenakan perbedaan pendapat yang tidak berujung. Semua agama mensyariatkan untuk beretika sopan santun, hidup damai walaupun dalam perbedaan, serta tunduk terhadap norma-norma yang berlaku di dalam masyarakat. Karena dalam masyarakat sendiri terdiri dari beranekaragam budaya, bahasa, suku, dan agama. Sehingga di dalam agama pasti mengajarkan umatnya untuk berbuat baik secara universal kepada siapaun dan dimanapun (M. Maftuh Basyuni, 2008: 5). Pluralisme di Indonesia sempat ternodai oleh beberapa konflik yang mencuat ke permukaan, konflik yang ada tersebut juga beragam baik konflik politik, suku, maupun agama. Yang mana konflik tersebut terjadi di sebabkan karena adanya konflik politik kawasan negeri maupun kawasan dunia (Muhammad Adib, Nur Qomari, 2017: 7).

\section{Pembahasan}

\section{Pluralisme}

Secara etimologi pluralisme berawal dari bahasa latin yaitu plus, pluris yang memiliki makna "lebih"( Mifta Ulya, 2013: 107). sedangkan dalam bahasa Inggris, pluralisme berasal dari kata plural (adj) yang merupakan kata sifat yang mana memiliki makna jamak (lebih dari satu)( English Dictionary, 2000: 971). Secara terminologi pluralisme merupakan suatu sikap yang menekankan kenyataan atas suatu kemajemukan setiap individu yang hidup 
bersama dalam suatu masyarakat. Pluralisme mengajarakan bahwa tidak ada agama yang sama, akan tetapi pluralisme lebih menekankan pada sikap keterbukaan antar sesama. Dalam hal ini sikap yang lebih di utamakan adalah sikap saling menghargai, saling menghormati, saling tolong-menolong, saling menjaga, dan tenang tidak saling terganggu antar sesama manusia dalam skala global yang bersifat jamak (Mifta Ulya, 2013: 170). Tujuan dari pluralisme sendiri yaitu untuk menghasilkan komunikasi yang baik, yang juga dapat menghubungkan antara ketidaktahuan serta kesalahpahaman budaya yang tidak sama, yang dialami oleh kelompok mayoritas dan kelompok minoritas, sehingga kelompok-kelompok tersebut dapat berbicara dan mengutarakan ide-ide dalam pemahaman mereka dengan di depan publik. Dalam hal ini pluralisme yang menjadi sorotan adalah pandangan pluralisme dari Abdurrahman Wahid atau yang akrab disapa Gus Dur, yang mana beliau berusaha memperkenalkan pada dunia bahwa pluralisme yang terjadi di dalam masyarakat merupakan perbedaan dalam hal budaya, bangsa, bahasa, etnis, ras, suku, warna kulit, serta agama (Eko Setiawan, 2017: 57).

Pluralisme dalam pandangan beberapa tokoh lintas agama, antara lain yaitu: Pertama menurut Diana L ECK, yang mana telah mengelompokan pluralisme menjadi empat bagian, yaitu: pluralisme bukan hanya tentang keragaman semata, tetapi harus di ikuti pula dengan perjumpaan dan hubungan yang baik di antara semuanya, pluralisme bukan hanya tentang toleransi di antara perbedaan tetapi juga ikut andil untuk memahami seluruh garis perbedaan, pluralisme bukan berarti relativisme yang membuat kita harus meninggalkan identitas siapa diri kita dengan meragukan apa yang telah kita yakini, namun dalam pluralisme yang terjadi sebenarnya hanyalah perjumpaan dari berbagai komitmen yang ada, sehingga akan lebih menguatkan iman seorang, pluralisme didasarkan pada dialog (Diana L. Eck : 2002).

Kedua pandangan Abdurrahman Wahid (Gus Dur) tentang Pluralisme yang di dasarkan pada pemikirannya bahwa semua manusia itu sama, tidak ada yang membedakan baik dari suku, bangsa, ras, etnis, warna kulit, jenis kelamin. Menurut Gus Dur Pluralisme tidak berarti bahwa semua agama itu sama. Hal ini karena secara teologis dalam setiap aqidah tidak di benarkan apabila sampai menganggap bahwa semua agama itu sama, namun setiap agama pasti mengajarkan kepada umatnya untuk berbuat baik kepada sesamanya baik yang seiman maupun yang tidak seiman Eko Setiawan, 2017: 62). Pluralisme dalam pandangan Gus dur merupakan suatu usaha yang dilakukan untuk membangun sebuah bangsa dengan tujuan agar dapat hidup rukun dan damai tanpai adanya pertententangan dengan di dasarkan pada sikap toleransi yang tinggi. Karena bangsa yang majemuk seperti Indonesia berpeluang 
besar dengan mudah tersulut ketegangan, permusuhan, dan kekerasan jika salah dalam pengelolahan.

Ketiga, Menurut Kuntowijoyo sebagaimana yang ditulis oleh Lani Rofiqoh dan Aris Suherman yang menyatakan bahwa pluralitas merupakan suatu kemajemukan yang tidak dapat dielakan lagi kebenarannya, sebagaimana adanya kaum laki-laki dan perempuan, muda dan tua, berkulit putih dan hitam, berbeda-beda keyakinan, dan lain sebagainya. Hal ini dapat menjadi bukti bahwa kemajemukan itu tidak lepas dari pluralisme. Dan itu merupakan suatu kesalahan jika digadang sebagai suatu hal penyesatan (Lani Rofiqoh, Aris Suherman, 2017: 170).

Keempat, menurut Nurcholish Madjid sebagaimana yang di tulis oleh Aris Kristanto, yang mendefinisikan bahwa pluralisme itu tidak hanya memberi pengertian terhadap adanya sikap mau menerima dan mengakui hak-hak orang ataupun kelompok lain, akan tetapi diperlukannya sikap yang mengarah pada kesediaan untuk saling berlaku adil antar sesama atau kelompok satu dengan kelompok lain dengan berasaskan pada perdamaian dan sikap yang saling menghargai (Aris Kristianto, 2005: 41). Bersikap pluralis sangat diperlukan dalam menghadapi keberagaman yang ada di Indonesia. Hal ini dibutuhkan supaya di negara yang beragam ini tidak terjadi permusuhan antar sesama umat beragama. Sedangkan menurut Baydhawy sebagaimana yang ditulis oleh Lani Rofiqoh dan Aris Suherman mengelompokan sikap-sikap yang dianggap tergolong sebagai sikap pluralis, antara lain: pertama, hidup dan tinggal dalam perbedaan yang mana hal tersebut mencerminkan suatu sikap toleransi yang dalam bahasa Arab hal tersebut disebut dengan Tasamuh. Kedua, sikap untuk saling menghargai satu sama lain. Ketiga, sikap saling percaya dan mempercayai satu sama lain baik orang ataupun kelompok lain. Keempat, sikap yang saling ketergantungan antar satu sama lain. Dan yang kelima, sikap mengapresiasi perbedaan budaya (Lani Rofiqoh, 2017: 140).

Menurut Al-Qaradhawi sebagaimana yang ditulis oleh Muhammad Yunus membagi faktor penyebab dari toleransi dibagi menjadi empat bagian, faktor tersebut antara lain: pertama, kepercayaan kepada keutamaan serta kemulian manusia yang tidak memandang suku, bangsa, etnis, ras, dan agama. Kedua, kepercayaan bahwa adanya perbedaan yang terjadi terutama dalam hal keyakinan dan agama adalah suatu kenyataan yang di kehendaki oleh Yang Maha Kuasa, yang mana hal itu telah diberikan hak kebebasan untuk memilih beriman ataupun tidak. Oleh karena itu, tidak diperbolehkan untuk memaksakan kehendak pribadi. Seperti memaksakan orang yang berbeda agama harus menjadi seiman dengan kita. 
Ketiga, sebagai seorang muslim, kita tidak diperintahkan untuk mengadili dan menghukum kekafiran kepada orang kafir. Hal ini dikarenakan hanya Allah Swt-lah yang nantinya akan mengadili orang-orang yang pernah hidup di dunia sesuai dengan amal perbuatan masingmasing orang. Sehingga sebagai seorang muslim kita dapat hidup dengan tenang tanpa perasaan was-was. Keempat, kepercayaan bahwa Allah Swt menyuruh makhluk-Nya untuk selalu berbuat baik dan bersikap adil terhadap sesama baik yang seiman maupun yang tidak seiman. Hal ini karena Allah Swt membenci perbuatan dzalim (Muhammad Yunus, 2017: 171).

Menurut Alwi Sihab sebagaimana yang di tulis oleh Miftah Arifin dan Zainal Abidin menyatakan bahwa pluralisme itu bisa mencegah individu ataupun kelompok disetiap penganut agama dari sikap-sikap negatif seperti halnya sikap absolutisme yang merupakan sikap sombong yang dikarenakan pengaruh dari intelektual dan eksklusivisme, yang merupakan sikap sombong karena dipengaruhi oleh faktor sosial. Fanatisme yang merupakan bagian dari sikap sombong karena dipengaruhi oleh emosional, ekstreamisme yang merupakan sikap yang berlebih-lebihan dalam menanggapi suatu hal, dan agresivisme yang merupakan sikap berlebih-lebihan dalam mengerjakan suatu tindakan fisik (Miftah Arifin, Zainal Abidin, 2017: 21).

\section{Landasan Pluralisme dalam Agama-agama}

Dalam agama islam juga mengajarkan pada umatnya untuk saling berbuat baik kepada sesama manusia tidak memandang suku, bangsa, ras, etnis, dan agama. Karena pada hakikatnya semua manusia itu sama di mata Allah Swt yang membedakan mereka hanyalah imannya. Berbuat baik itu meliputi beberapa sikap, antara lain saling tolong menolong, menghargai, tidak menganggu, tidak menghina dan sebagainya. Pluralisme dalam agama Islam merupakan suatu pemahaman yang menerima adanya perbedaan dan menyikapinya dengan kebaikan sehingga menimbulkan suatu sikap toleransi. Sebagaimana yang tertulis didalam kitab suci Al-Qur'an surat Al-Kafirun ayat 1-6, yang berbunyi:

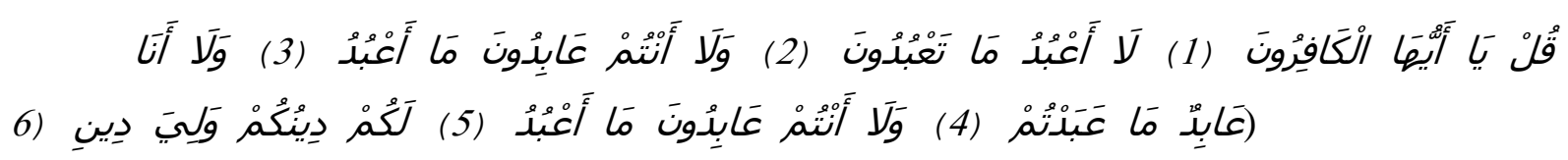

Terjemahannya: "Katakanlah: Hai orang-orang kafir, Aku tidak akan menyembah apa yang kamu sembah, Dan kamu bukan penyembah Tuhan yang aku sembah. Dan aku tidak pernah menjadi penyembah apa yang kamu sembah, dan kamu tidak pernah menjadi 
penyembah Tuhan yang aku sembah. Untukmu agamamu, dan untukkulah, agamaku" (AlQur'an).

Para ahli telah mengambil beberapa kesimpulan dari kandungan surat Al-Kafirun ayat 1-6. Kesimpulan tersebut antara lain: pertama, tidak diperbolehkan untuk seseorang memaksakan kehendak pribadinya dalam hal memaksa orang lain agar memeluk agama yang di yakininya dengan meninggalkan ajaran agama yang sudah dianutnya. Kedua, setiap manusia memiliki hak untuk melakukan peribadatan masing-masing sesuai dengan ajaran agama yang dipeluknya (Mohamad Rijal, 2018: 288). Dengan demikian dapat ditarik kesimpulan bahwa surat Al-Kafirun ayat 1-6 mengajarkan bahwa suatu agama tidak dapat ditukar dengan agama lain, serta setiap agama memiliki cara peribadatan masing-masing menurut keyakinan yang dianutnya. Setiap agama pasti diajarkan tentang kedamaian, begitupun dalam agama Islam. Yang mana Islam sendiri adalah agama yang cinta damai, tidak mengajarkan kekerasan, dan juga agama yang lembut. Selain itu, juga terdapat beberapa ayat dalam kitab suci al-Qur'an yang mengatakan tentang hal-hal tersebut. Seperti yang tertulis dalam al-Qur'an surat al-Hujarat ayat 13, yang tertulis sebagai berikut:

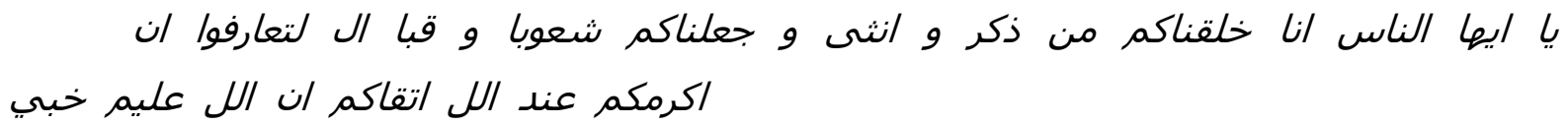

Terjemahannya: "Hai manusia sesungguhnya kami menciptakan kamu dari seorang laki-laki dan perempuan, dan menjadikan kamu berbangsa-bangsa dan bersuku-suku supaya kamu saling kenal mengenal. Sesungguhnya orang yang paling mulia diantara kamu disisi Allah ialah orang yang paling bertakwa diantara kamu. Sesungguhnya Allah maha mengetahui lagi maha mengenal"(Al-Qur'an). Isi kandungan yang terdapat di dalam Surat Al-Hujarat ayat 13 tersebut menjelaskan tentang kenyataan pluralisme yang merupakan Sunnatullah (hukum alam) yang tidak dapat dihindari oleh siapapun. Pada dasarnya pluralisme itu ada karena terlahir dari perbedaan, yang meliputi beberapa hal terutama dalam kekhususan ciri-ciri yang terdapat dalam semua ciptaan Tuhan (Nova E. Mohamad, 2013: 72). Agama islam mengajarkan umatnya untuk saling mengenal satu sama lain tanpa harus membedakan antar satu dengan yang lainnya. Perkenalan tersebut dilandasi dengan sikap tasamuh (toleransi) saling memahami dan menghormati antar sesama umat beragama.

Sedangkan pluralisme dalam agama kristen merupakan ajaran kasih sayang kepada sesama manusia yang tidak memandang ras, suku, bangsa, bahasa, etnis, dan agama. Sebagaimana terdapat dalam ajarannya yang mengajarkan hukum kasih sayang (kasih kepada Allah dan Kasih kepada sesama). Mengutib dari ayat Injil yang berbunyi "Jikalau seorang 
berkata "Aku mengasihani Allah", dan ia membenci saudaranya, maka ia adalah pendusta", karena barang siapa tidak mengasihi saudaranya yang dilihatnya, tidak mungkin mengasihi Allah, yang tidak dilihatnya" (Al Kitab). Hal ini jika dilogikakan sebagaimana dia yang tidak bisa mengasihani saudaranya, maka tentulah dia juga tidak bisa mengasihani Tuhannya. Dimana dapat digambarkan dengan sederhana, jika kita sebagai manusia tidak dapat mengasihi sesama maka tidak mungkin juga kita dapat mengasihi Tuhan kita yang Maha Tinggi. Oleh karena itu wajib bagi umat Kristen untuk mengasihani sesama, karena jika kita dapat mengasihani sesama maka otomatis kita juga dapat mengasihani Allah. Karena hal ini merupakan inti dari ajaran Yesus Kristus, jadi mengasihani sesama tidak harus memandang suku, bangsa, etnis, ras, dan agama. Dalam agama Kristen sendiri toleransi itu tidak hanya sekedar tidak saling menganggu saja, akan tetapi lebih dari itu. Yang mana kita harus saling bertegur sapa, berdialog, dan mengasihi antar sesama. Karena dari sinilah perdamaian dapat terwujud.

Agama Hindu mengajarkan pada umatnya untuk berbudi pekerti luhur, dengan menjunjung tinggi nilai-nilai kemanusian dan menyebarkan kasih sayang. Pada hakikatnya umat Hindu beribadah dan menyembah Tuhan yang Esa (Sang Hyang Widhi Wasa). Namun, dalam kitab-kitab penyebutan Tuhan Yang Esa itu beragama nama, sehingga memunculkan banyak sebutan nama untuk Tuhan Ynag Esa. Sebagaimana dijelaskan dalam kitab Regveda 1.164.46 yang berbunyi: "Tuhan Yang Maha Agung adalah Tunggal. Mereka yang bijak memanggilNya dengan sebutan yang berbeda-beda"( Kibat Rgveda I.164: 46). Dalam ajaran agama Hindu dijelaskan bahwa setiap manusia diperbolehkan untuk mengambil jalan yang berbeda-beda dalam menyembah Tuhan. Akan tetapi jalan tersebut tidak boleh berlawanan dengan nilai kemanusian. Sebagaimana diterangkan dalam kitab Bhagawadgita IV.11, yang berbunyi: “Apa pun jalan yang telah ditempuh manusia untuk mendekati-Ku, Aku akan menerimanya. Manusia dari manapun yang telah mengikuti jalan-Ku, Oh Partha"( Kitab Bhagawadgita Iv:11). Maka dapat ditarik kesimpulan bahwa manusia itu bebas memilih jalan dalam beragama sesuai kehendaknya masing-masing. Akan tetapi jalan tersebut tidak boleh bertentangan dan berlawanan dengan peri kemanusiaan.

Pluralisme dalam agama konghucu Sebagaimana tercantum dalam kitab Su Si, Lun Yu. IX. 30: "Yang dapat diajak belajar bersama belum tentu dapat diajak bersama menempuh jalan suci (beragama), yang diajak bersama menempuh jalan suci belum tentu dapat diajak bersama berteguh, yang dapat diajak berteguh belum tentu dapat bersesuaian paham" (Kitab Lunyu Ix: 30). Hal ini dapat diambil kesimpulan bahwa setiap orang memiliki 
pandangannya masing-masing, yang mana pandangan tersebut tentulah berbeda antar satu dengan yang lainnya. Oleh karena itu, sebagai warga beragama yang beragam kita tidak diperbolehkan menuntut seseorang yang berbeda keyakinan untuk ikut bergabung dengan keyakinan kita. Sedangkan, sikap toleransi dalam pluralitas menurut agama Konghucu diceritakan bahwa Nabi Kongzi tidak mendidik umatnya untuk melebihi umat lain. Dalam artian tidak diperintahkan untuk mencari dan menambah pengikut dengan cara merebut pengikut agama lain. Hal ini juga dijelaskan dalam kitab Su Si, Lun Yu, XII. 23 yang berbunyi: "seorang Junzi/Susilawan dapat rukun meski tidak sama, seorang rendah budi dapat sama meski tidak dapat rukun" (Kitab Lunyu Xiii : 23). Ayat tersebut mengajarkan bahwa sebagai umat beragama tidak di benarkan untuk memperdebatkan kebenaran dari masingmasing agama yang diyakininya. Karena kepercayaan beragama merupakan Hak Asasi Manusia (Gunandi, Hartono , 2002: 149). Oleh karena itu sebagai umat beragama yang menjunjung tinggi nilai-nilai kemanusia, seharusnya kita dapat merangkul sebuah perbedaan tanpa harus menyakitinya. Karena adanya perbedaan membuat kita mengerti akan indahnya keberagaman.

Dalam agama Buddha mengajarkan pemeluknya akan ajaran kebenaran yang lebih dikenal dengan sebutan "dharma"( I Gusti Made Widya Sena, 2015: 111). Ajaran untuk saling menghargai dalam perbedaan dijelaskan dalam Pancasila Buddhis yang mana dijakdikan sebagai patokan hidup untuk mengatur kehidupan sehari-hari agar tidak kacau. Pancasila Buddhis sendiri memiliki sila-sila (aturan) yang harus di jadikan patokan agar terhindar dari hal-hal yang tidak terpuji. Isi dari sila-sila itu antara lain: pertama, berisikan perintah untuk tidak membunuh makhluk hidup baik itu bintang maupun manusia. sila 1 berbunyi: "Panatipata Veramani sikkhapadang samadiyami" yang memiliki arti bahwa pelatian diri untuk menjauhi pembunuhan makhluk hidup. Dalam hal ini agama Buddha mengajarkan umatnya untuk mencintai makhluk ciptaannya dengan tidak diperbolehkannya menyiksa bahkan samapi membunuhnya. karena perbuatan membunuh merupakan perbuatan keji dan tercela. Kedua, berisikan larangan mengambil bahkan mencuri barang orang lain. Perintah ini sesuai dengan sila ke-2 yang berbunyi: "Adinnadana veramani sikkha padang samadiyami" yang memiliki arti bahwa pelatihan diri untuk menjauhi perbuatan mencuri. Dalam hal ini agama Buddha mengajarkan umatnya untuk tidak mengambil apa yang bukan miliknya. Karena mengambil barang orang lain merupakan perbuatan yang merugikan orang lain. Ketiga, berisikan perintah untuk menjauhi perbuatan tak bermoral. Perintah ini sesuai dengan sila ke-3 yang berbunyi: "Kamesumicchacara Veramani 
sikkhapadam samadiyami" yang memiliki makna bahwa pelatihan diri untuk menjauhi perbuatan tak bermoral dan tak beretika. Dalam hal ini agama Buddha mengajarkan umatnya untuk berfikir jernih sehingga dapat membedakan perbuatan yang baik dan yang buruk. Yang mana sudah dapat mengendalikan nafsunya untuk tidak berbuat asusila. Keempat, berisikan perintah menghindari perkataan kotor. Perintah ini sesuai dengan sila ke-4 yang berbunyi: "Musavada Veramani sikkhapadam samadiyami. Yang mana memiliki makna bahwa pelatihan diri untuk menjauhi berkata-kata kotor baik pada anak-anak, remaja, maupunorang tua. Dalam hal ini agama Buddha mengajarkan umatnya untuk tidak berkata-kata kotor, mengomongkan orang laindi belakangnya, bahkan memfitnahnya. Kelima, berisikan perintah menjauhi perbuatan yang dapat memadamkan kewaspadaan. Perintah ini sesuai dengan sila ke-5 yang berbunyi bahwa: "Suramerayamajjapamadatthana Veramani sikhapadang samadiyami”. Yang mana memiliki artian bahwa pelatihan diri untuk menjauhi sesuatu hal yang dapat memecah belah konsetrasi. Dalam hal ini agama Buddha mengajarkan umatnya untuk menjauh dari perbuatan yang tidak baik yang dapat membuyarkan konsentrasi seseorang (Febrian Ariya Passaddhi, 3).

\section{Realitas Pluralisme Bangsa Indonesia}

Realitas keberagaman negara Indonesia di warnai dengan adanya peristiwa-peristiwa intoleransi yang berujung pada penilaian citra keagamaan. Hal tersebut menyebabkan penodaan pada sejarah agama-agama yang awalnya bersikap toleransi menjadi intoleransi (Zuhairi Misrawi, 2007: 178). Sikap intoleransi sebagai pemicu terjadinya konflik-konflik dalam masyarakat yang mengatasnamakan agama. Pada dasarnya konflik agama disebabkan oleh sikap tertutupnya suatu orang atau kelompok beragama dalam menerima pendapat orang atau kelompok lain, sikap ini biasa di sebut dengan "ekslusivisme”( Abd A'la, 2002: 33). Indonesia sebagai negara yang berdaulat dengan menjunjung tinggi nilai-nilai kemanusian memiliki peranan penting dalam melindungi kerukunan dan keharmonisan antar umat manusia, tanpa adanya tembok pembatas yang menyekat baik dalam bahasa, etnis, ras, dan agama. Oleh karena itu, disahkannya UU Nomor 11 Tahun 2005 yang mengatur tentang ICESCR (International Covenant on Economic, Social, and Culture Right) pada tanggal 28 Oktober Tahun 2005. Serta disahkan pula UU Nomor 12 Tahun 2005 yang mengatur tentang ICCPR (International Covenant on Civil and Political Right) (Asep Lukman Hamid, 2018: 122).

Indonesia juga tergolong sebagai negara yang multikultural (beranekaragam) baik dari latar belakang budaya, etnis, bahasa, maupun agama. Namun, dari keragaman tersebut 
banyak juga masyarakat yang tidak mengerti akan arti dari keragaman yang ada. Sehingga munculah konfilk-konfik dalam masyarakat yang di karenakan adanya perbedaan dalam keragaman itu. Konflik-konflik yang muncul tersebut tercuat kemasyarakat yang disebabkan karena kurangnya pemahaman toleransi antar umat beragama. Kebanyakan konflik yang terjadi di masyarakat merupakan konflik yang mengatasnamakan agama. Di Indonesia konflik yang mengatasnamakan agama diawali pada tahun 1999 di Ambon yang terjadi setelah adanya peristiwa reformasi. Konflik ini tepatnya terjadi pada 19 Januari 1999 sampai 22 Februari 2002 yang mana meninggalkan banyak korban jiwa, kerusakan, dan kerugian (Ruri Puji Hastuti, 2017:2).

Akhir akhir ini memasuki tahun politik konflik yang mengatas namakan agama terjadi lagi, baik di ibu kota maupun di kota-kota lainnya. Dimulai pada tahun 2016, dengan adanya kasus penistaan agama yang dilakukan oleh tokoh pemerintah mantan Gubernur DKI Jakarta, Basuki Tjahaja purnama yang lebih dikenal dengan sapaan Ahok, Ia dituduh telah melakukan penistaan agama Islam dalam pidotanya di Kepulauan Seribu pada 27 September 2016 (Yantina Debora, 2016). Dari kasus tersebut munculah kasus- kasus baru yang mengatas namakan agama. Seperti contoh kasus aksi bela Tauhid yang dilakukan oleh sebagaian umat Islam atas nama Barisan Nusantara Pembela Tauhid (BNPT) yang dilakukan oleh sebagai balasan atas tindakan pembakaran bendera yang diduga bendera HTI oleh Banser Nu di Garut Jawa Barat (Mohamad Amin Madani, 2018). Tidak hanya itu, kasus intoleransi juga semakin bermunculan di masayarakat luas, seperti adanya kasus pengeboman di tiga gereja sekaligus yaitu yang pernah terjadi di Surabaya pada 13 Mei 2018. Pengeboman tersebut berlokasi di tiga tempat yaitu: di jalan Ngagel Jaya, Gereja Maria Tak Bercela, di Jalan Diponegoro dengan Gereja Kristen Indonesia (GKI), dan di Jalan Arjuna dengan Gereja Pantekosta (Palupi Annisa Auliani, 2018). Dimana atas terjadinya peristiwa tersebut apabila setiap individu atau dua agama tersebut tidak dapat mengelola perbedaan dengan baik, maka konflik tersebut akan mudah terjadi dan tumbuh menjadi besar.

Konflik atas isu agama sangat mudah muncul kepermukaan, sebagai bentuk rasa emosioanal yang tidak dapat dibendung. Hal ini sejalan dengan teori konflik George Simmel yang telah menjadi rujukan bagi Ritzer dan Goodman, menyatakan bahwa konflik itu muncul dikarenakan adanya perasaan emosional umat beragama (Nazmudin, 2017: 25). Konflikkonflik yang terjadi di atas merupakan peristiwa yang harus dihindari bahkan seharusnya tidak terjadi. Karena disetiap ada konflik baik yang mengatasnamakan negara, politik, sosial, budaya, maupun agama pastilah akan menimbulkan kekacauan, kerusakan, kehancuran 
bahkan kehilangan jiwa raga. Konflik antar umat beragama sebagaimana pandangan Maftuh Basyuni dapat dijauhi dengan penekanan sikap kebijaksanaan melalui kedewasaan dalam menyikapi hal-hal yang berbeda dalam setiap kelompok keagamaan (M. Maftuh Basyuni, 2008: 3). Oleh karena itu, pemerintah Indonesia seharusnya dapat mengayomi umat beragama dengan menerapkan sikap toleransi antar sesama. Penerapan sikap saling menghargai dapat dilakukan sejak usia dini, dengan cara mengenalkan anak akan keberagaman di Indonesia seperti berbuat baik, saling tolong menolong antar sesama. Penerapan sikap saling menghargai yang berasaskan pada dasar negara Indonesia yaitu Pancasila yang bisa dilakukan disekolah dapat dilakukan dengan berbagai cara, antara lain yaitu: 1. Mewajibkan Menyanyikan lagu-lagu kebangsaaan sebelum melakukan kegiatan belajar mengajar. Hal tersebut bertujuan memunculkan kesadaran akan keberagaman (pluralis) yang ada di Indonesia. 2. Mewajibkan guru-guru bersikap pluralis dalam kehidupan sehari-hari baik di sekolah maupun di lingkungan masyarakat, sehingga para siswa dapat meneladani sikap tersebut. 3. Mewajibkan guru-guru dalam memberikan materi pelajaran di imbangi dengan materi tentang keberagaman dan toleransi. 4. Mewajibkan guru-guru untuk mengingatkan anak didiknya untuk selalu menjaga dan mengamalkan sikap toleransi. 5. Mewajibkan berdoa sebelum belajar dimulai (Riyanto, Halili, 2018: 609).

Pluralisme di Indonesia melahirkan hak-hak manusia untuk memilih agama menurut kepercayaannya masing-masing. Hal ini tercantum dalam Undang-Undang Dasar (UUD) Negara Republik Indonesia tahun 1945 Pasal 28 E ayat 1 yang menyatakan bahwa "Setiap orang bebas melakukan agama dan beribadah menurut agamanya, memilih pendidikan, dan pengajaran, memilih pekerjaan, memilih kewarganegaraan, memilih tempat tinggal di wilayah negara atau meninggalkannya, serta berhak kembali” (Sonie Setiawan, Listyaningsih, 2018: 107). Dalam Undang - Undang Dasar tersebut menjelaskan bahwa setiap warga negara Indonesia diperbolehkan untuk memilih agama menurut kepercayaannya masing-masing tanpa adanya paksaan dari orang lain. Jadi setiap orang dilarang memaksakan kehendaknya untuk menyuruh orang lain supaya ikut memeluk kepercayaannya. Hal tersebut tergolong dalam pelanggaran Hak Asasi Manusia, karena Negara memiliki kewajiaban menjamin hakhak kebebasan beragama untuk umat beragama di Indonesia. Bersikap pluralis juga dapat dilakukan dengan cara berdialog antar umat beragama dengan menyisipkan nilai-nilai toleransi didalamnya. Hal tersebut diperlukan guna untuk mempererat persatuan dan kesatuan bangsa indonesia. Tidak hanya itu dialog agama juga dapat mengikis dan menghapuskan konflik-konflik yang timbul di masyarakat beragama (Afif Rifa'I, 2017: 91). 
Tapi pada kenyataanya pemerintah Indonesia melalui Kementerian Agama telah menyisipkan materi-materi toleransi pada kurikulum pendidikan dasar tingkat Madrasah Tsanawiyah (Darwyan Syah, 2013: 315). Hal sebagai penunjang pengajaran nilai-nilai toleransi pada tingkat remaja dalam menyikapi kemajemukan (pluralitas). Pendidikan di Indonesia bermuara pada konsep pluralisme, menurut J. A. Banks menggolongkan kerangka perubahan kurikulum mengunakan macam-macam pendekatan, antara lain: 1) pendekatan kontributif yang memiliki tujuan untuk menyisipkan konsep-konsep kemajemukan agama, budaya, dan sosial. 2) pendekatan aditif yang bertujuan untuk memberikan tambahan materimateri baru ke dalam kurikulum pembelajaran tanpa mengubahnya (M. Amin Abdullah, 1993: 88-89). Standar kurikulum di sekolah-sekolah mengalami perubahan dalam kompetensi kelulusannya, hal ini termuat dalam Peraturan Menteri Pendidikan Nasional Tanggal 23 Mei Nomor 23 Tahun 2006 yang menjelaskan bahwa peserta didik dalam semua jenjang pendidikan dirasa mampu menerapkan sikap menghargai keberagaman baik itu dalam budaya, bahasa, etnis,maupun agama yang terdapat di masyarakat (Peraturan Menteri Pendidikan Nasional, 2006).

\section{Tanggapan Remaja Lintas Agama Atas Realitas Pluralisme Di Indonesia}

Remaja muslim beranggapan bahwa Pluralisme itu merupakan ciri khas orang Indonesia, dimana setiap agama dapat hindup berdampingan dengan bagus. Contoh kongkritnya dapat ditemui di masjid Al-Akbar Surabaya yang di belakangnya terdapat Gereja, akan tetapi masyarakat disana dapat hidup harmonis tanpa adanya permusuhan. Akan tetapi akhir-akhir ini keharmonisan tersebut mulai berkurang, hal ini di karenakan semenjak tahun 2016 memasuki dekada-dekada politik yang kuat, pluralisme di Indonesia di uji dengan keberadaan dekada politik. Sehingga terdapat beberapa kasus politik yang mengatasnamakan agama. Seperti contoh kasus penistaan agama di Ibu Kota, umat Islam radikal yang mana bersudut pandang keras mengecam kasus tersebut dengan ikut melakukan aksi, sehingga mengakibatkan terjadinya kasus kriminal di pertahanan negara Indonesia. Kasus aksi tersebut mendapat sambutan kurang baik dari pemuda Maluku yang mayoritas beragama Kristen menuntut pihak-pihak yang melakukan aksi. dengan melakukkan aksi balik. Oleh karena itu kita pemuda penerus bangsa harus cerdas dan cermat dalam menyikapi peristiwa-peristiwa yang mengandung unsur SARA didalamnya. Karena dari peritiwa-peristiwa tesebut merupakan faktor utama pemecah bangsa. Kita pemuda seharusnya menyebarkan kedamain dalam perbedaan, bukan ikut andil dalam permusuhan. Karena dalam perbedaan pasti ada keragaman. Dan keragaman merupakan suatu hal terindah yang diciptakan Tuhan (Agus 
Nafi', 2018). Sebagai agama dengan pemeluk mayoritas di kota Surabaya, umat Islam hendaknya mampu merangkul berbagai kelompok yang ada di kota Surabaya, meski perlu dippahami juga bahwa dalam tubuh Islam sendiri terdapat beragam kelompok yang berbeda dalam memahami hubungan antar umat beragama. Menurut Agus, peran Kyai dan Ulama' sangatlah sentral dalam turut serta memberikan pemahaman toleransi pada umatnya, narasinarasi wasatiyah dalam ceramah yang disampaikan oleh elite keagamaan perlu diperluas dalam berbagai forum keagamaan, hal ini untuk menambah wawasan toleran bagi umat beragama sehingga tidak hanya memegang truth claim sebagai satu-satunya realitas keagamaan. Kejadian terror di kota Surabaya beberapa waktu yang lalu cukup dijadikan sebagai bahan evaluasi bagi semua pihak agar kedepannya tidak terjadi lagi, sikap pluralis dalam bermasyarakat perlu ditonjolkan untuk menangkan tumbuhnya benih-benih paham radikal yang menyebabkan terjadinya disintregasi bangsa.

Pandangan remaja kristen tentang pluralisme yang mana bahwa pluralisme itu merupakan suatu paham yang tidak menyamaratakan bahwa semua agama didunia ini sama. Akan tetapi setiap agama memiliki keunikannya dan kekhasan masing-masing untuk membedakan satu sama lain. Adanya pluralisme itu sebagai wadah mengenal satu sama lain secara utuh tidak katanya-katanya lagi dalam artian tidak hanya sebatas percaya omongan tanpa adanya pembuktian yang pasti. Karena dimulai dari sikap saling kenal mengenal satu sama lain akan timbul sikap menghargai kemudian akan muncul sikap kasih sayang, sehingga akan tercapai perdamaian. Sebagai anak bangsa kita harus bersyukur karena Indonesia diciptakan Tuhan dengan keragaman baik dalam budaya, bahasa, etnis, dan agama. Hal ini merupakan fakta yang tidak dapat dipungkiri kebenarannya. Oleh karena itu para Founding Father menetapkan Slogan "Bhinneka Tunggal Ika" dijadikan sebagai semboyan bangsa untuk menyatakan keragaman bangsa Indonesia. Sebagai orang Kristen yang taat dia bersyukur karena hal ini merupakan suatu kesempatan untuk meneladani ajaran Isa Al-Masih yaitu dengan mengasihani sesama. Bukan hanya sesama Kristen akan tetapi kepada sesama umat manusia. yaitu dengan cara saling mengenal dan memahami satu sama lain. Dengan tetap menyakini apa yang dianut oleh masing-masing umat (Josua Bernard Kristiani, 2018). Lanjut Joshua, menurutnya kondisi realitas keberagamaan di kota Surabaya sudah sangat kondusif, akan tetapi ada beberapa kejadian menonjol yang menyita perhatian public, diantaranya seperti peristiwa bom tiga Gereja di Surabaya yang telah menyebabkan jatuhnya korban jiwa. "Setiap kejadian yang melanggar nilai-nilai kemanusiaan maka pelakunya harus mendapatkan hukuman sesuai dengan aturan hukum yang berlaku di Indonesia, dengan 
alasan apapun itu melakukan kekerasan hingga menyebabkan nyawa manusia melayang merupakan tindakan yang tidak bisa diterima oleh agama", imbuh Joshua.

Sedangkan menurut remaja Buddha Pluralisme itu merupakan satu kata yang mampu mendeskripsikan perbedaan, kemajemukan dari sebuah ras, suku, agama, dan budaya. Dalam agama Buddha sendiri mengajarkan umatnya untuk senantiasa menjunjung tinggi toleransi antar umat manusia. Serta pluralisme itu dijadikan sebagai hal-hal yang bernilai positif. Agama Buddha itu terdiri dari banyak aliran, perbedaan, dan keragaman budaya. Sedangkan realitas pluralisme di Indonesia sendiri sudah baik tetapi perlu ditingkatkan lagi. Hal ini dikarenakan Indonesia merupakan negara yang majemuk dengan segala keanekaragamannya. Akan tetapi masih banyak masyarakat Indonesia yang tidak menyadari keragaman tersebut. Sehingga masih ada sebagian masyarakat yang membenci keragaman yang ada di sebabkan perbedaan. Oleh karena itu kita sebagai generasi penerus bangsa harus mampu menggembangkan nilai-nilai toleransi dengan cara menyebarkan kedamaian dimanapun, kapanpun, dan kesiapapun (Jesica, 2018). Jesica melihat realitas kerukunan beragama di kota Surabaya, hal ini dapat terlihat dari beragam kegiatan yang sering diselenggarakan oleh berbagai pihak yang peduli terhadap kerukunan umat beragama di Surabaya. Dari beragam kegiatan yang mempertemukan berbagai perbedaan umat beragama tersebut dapat memunculkan nilai toleran dan pemahaman pluralis dalam diri masing-masing umat beragama. Sehingga perlu dukungan seluruh pihak untuk terus menjaga kerukunan umat beragama sehingga masyarakat semakin memahami realitas pluralitas beragama di kota Surabaya", tambah Jesica.

Pluralisme dalam pandangan remaja Konghucu merupakan suatu keniscayaan yang dikarenakan Tuhan menciptakan seluruh makhluk beranekaragam, dan kita sebagai manusia yang berakal harus memahami hal tersebut. Agama Konghucu mengajarkan umatnya untuk saling berbuat baik kepada sesama manusia. hal ini sebagaimana dijelaskan dalam kitab Sishu yang berbunyi bahwa "seorang Junzi (seorang berbudi luhur) itu rukun meskipun tidak sama di empat penjuru lautan semua bersaudara, kalau ingin maju bantu orang lain untuk maju”. Dari ayat ini dapat ditarik kesimpulan bahwa antar sesama manusia di haruskan hidup rukun, saling tolong menolong, saling hormat menghormati, dan saling percaya satu sama lain. Karena pada dasarnya manusia itu merupakan makhluk sosial yang tidak dapat hidup sendiri mereka saling membutuhkan orang lain. Sedangkan realitas pluralisme di Indonesia sudah terlaksana dengan diamalkannya nilai-nilai Pancasila dan Bhinneka Tunggal Ika akan tetapi masih penuh hambatan. Hal ini dapat dilihat dari mudahnya bangsa Indonesia dipecah belah 
dikarenakan perbedaan dan kurangnya rasa nasionalisme (cinta tanah air) serta kurangnya rasa memilki terhadap bangsa sendiri. Oleh karena itu kita sebagai generasi muda penerus bangsa harus mampu memperjuangkan terwujudnya pluralisme di Indonesia. Kita harus belajar dari Founding Father bangsa ini dimana dalam mewujudkan cita-cita luhurnya harus bersatu padu tidak ada perbedaan baik itu dari suku, ras, etnis, bahasa, budaya, maupun agama. Jika kita sudah bersatu saling menghormati, tolong menolong, menghargai satu sama lain. Maka kita akan jadi bangsa yang hebat yang susah untuk dipecah belah (Surya: 2018). "Tak dapat dipungkiri bahwa sikap memahami relaitas pluralism merupakan hal yang penting bagi individu di tengah realitas keberagaman budaya, etnis dan agama yang ada di Surabaya. Sikap ini perlu dipahami oleh generasi muda kota Surabaya (sebagai penerus perjuangan) sebagai sebuah sikap fundamental dalam berbangsa dan bermasyarakat. Tak dapat dipungkiri juga bahwa kota Surabaya pernah mendapat ujian terror atas nama agama seprti bom tiga Gereja yang terjadi beberapa waktu lalu, kemudian masih belum dewasanya masyarakat dalam menerima pendirian rumah ibadat yang berbeda di lingkungannya. "lanjut Surya yang juga merupakan ketua Pemuda Konghucu ini.

Pluralisme dalam pandangan remaja Hindu merupakan suatu paham akan keberagaman yang dimiliki oleh setiap individu tentang bagaimana cara memaknai arti dari perbedaan. Konsep awal dari pluralisme itu sendiri adalah kebersamaan dalam suatu wilayah, daerah, maupun negara yang memiliki keanekaragaman budaya ketika kita menyadari keberagaman tersebut akhirnya perbedaan tersebut hanya menjadi suatu penghalang yang bahkan menjadi pengusik jati diri bangsa ini. Padahal yang paling utama jika dilihat dari perjalan bangsa kita sendiri terbentuknya Indonesia itu terdiri dari berbagai macam suku, ras, etnis, bahasa, budaya, maupun agama. Oleh karena itu seharusnya kita mampu membedakan mana budaya pribadi dan mana budaya adopsi. Sehingga kita mengerti dan tidak mudah terpancing emosi akan adanya berbedaan dalam budaya yang ada. tugas kita sebagai pemuda harus pintar menyaring informasi agar tidak mudah termakan hoax yang menjadi pemicu konflik di masyarakat. Jika kita dapat membedakan mana yang benar dan mana yang salah tentu kita tidak mudah dipecah belah, karena kita sudah saling percaya antar sesama (Putu, 2018). Dalam kondisi hubungan antar umat beragama di Surabaya, Putu menilai bahwa Surabaya merupakan slaah satu kota yang kondusif, iklim politik yang menggunakan beragama isu agama di ibu kota tidak sampai merusak hubungan antar umat beragama di kota Surabaya, hal ini menunjukkan adanya kesolidan dalam membangun hubungan antar umat beragama di Surabaya, Putu melihat peran pemerintah sangat central dalam turut serta 
membangun hubungan umat beragama melalui beragam program yang dilaksanakan, seperti kemah pemuda lintas agama, jamboree pemuda lintas agama, temu pemuda lintas agama, serta diskusi pemuda lintas agama yang rutin dilaksanakan. Beragam kegiatan tersebut menurut Putu merupakan cikal bakal dari munculnya sikap pluralis dalam jiwa pemuda kota Surabaya, dari sikap pluralis tersebut muncul nilai toleran dan saling menghormati antara satu dengan yang lain.

\section{Pemuda Sebagai Penerus Perjuangan Bangsa}

Masa remaja dikenal sebagai masa peralihan dari anak-anak menuju dewasa yang dipengaruhi oleh beberapa faktor antara lain: pertumbuhan, kejiwaan, emosional, lingkungan. Masa remaja dapat dikatakan sebagai masa yang penuh kegoncangan jiiwa (Dadang Sulaiman, 1995: 1). Pemuda merupakan generasi penerus bangsa yang harus dididik dan dibekali dengan dasar-dasar sikap cinta tanah air yang menjunjung tinggi persatuan dan kesatuan bangsa, sehingga tidak mudah dipecah belah oleh orang-orang luar. Dalam hal itu pendidikan kewarganegaraan menjadi salah satu poin penting dalam mengajarkan pemuda akan sikap nasionalisme (cinta terhadap tanah air). Seperti yang kita ketahui sejauh ini pendidikan kewarganegaraan merupakan mata pelajaran yang mengajarkan peserta didik akan nilai-nilai pancasila yang diterapkan dalam kehidupan sehari-hari. hal ini sejalan dengan pendapat Simorangkir sebagaimana yang ditulis oleh Agung Suharyanto dalam Jurnal Ilmu Pemerintahan dan Sosial Politik, yang mana menyebutkan bahwa pendidikan kewarganegaraan memiliki beberapa tujuan yang utama, antara lain yaitu: sebagai wadah dalam pemberian pemahaman dan pengarahan suatu hal yang baik dan positif, sebagai wadah dalam penanaman main set yang sejalan dengan dengan ideologi bangsa Indonesia (Pancasila) dan sikap bangsa Indonesia, sebagai wadah dalam penanaman ke anak usia dini tentang nilai-nilai kemanusia yang bermoral dan beradab. Dan sebagai wadah dalam pemberian pemahaman tentang pentingnya pelestarian norma-norma yang terdapat di Pancasila dengan dipraktikan dalam kehidupan sehari-hari (Agung Suharyanto, 2013: 195).

Sikap pluralisme dapat tumbuh dengan menerapkan sikap saling menghargai dan menghormati hak dan kewajiban umat beragama tanpa adanya perilaku diskriminasi dalam segala aspek kehidupan (Dede Rosyada, 2006: 33-34). Sikap pluralisme dapat terlihat dari sikap inklusif (terbuka) dalam artian dapat menerima pendapat-pendapat umat beragama lain yang tidak seiman dengannya (Mulyadhi Kartanegara, 2007: 89-91). Oleh karena itu pemahaman sikap inklusif diperlukan guna untuk menciptakan suatu hubungan yang damai antar umat beragama dalam keragaman yang ada (Abdurahman Kasdi, 2013: 223). adanya 
sikap inklusif dalam beragama menjadikan bahan perbekalan dalam menghadapi perkembangan zaman yang semakin hari semakin maju. Dalam hal ini Cak Nur (Nur Cholish Madjid) beranggapan bahwa sikap inklusif searah dengan ajaran teologis yang mana terdapat empat bagian didalamnya, antara lain: 1) Pluralitas (keberagaman) merupakan hukum alam yang tidak dapat dielakan oleh siapapun. 2) adanya penilaian dan pengakuan dari keberdaan dari semua agama. 3) adanya benang merah yang menghubungkan titik temu dari setiap agama. 4) dalam setiap agama tidak dibenarkan adanya intimidasi dari agama lain (Nurcholish Madjid, 1992: 602).

Dalam penyebaran nilai-nilai perdamaian media memiliki peranan penting didalamnya. Hal ini sejalan dengan pendapat Menurut Katz dan Blummer, sebagaimana yang di tulis oleh Ichwani dalam jurnal Pendidikan Kewarganegaraan, menjelaskan bahwa terdapat lima keperluan mendasar manusia dalam mengunakan media, keperluan tersebut antara lain yaitu: 1) keperluan kognitif yang merupakan keperluan tentang pentingnya wawasan pengetahuan, dan berita-berita seputar kehidupan sehari-hari. 2) keperluan afektif yang merupakan keperluan tentang persaan emosional sesorang baik itu kesenangan maupun kesedihan. 3) keperluan integratif yang merupakan keperluan tentang status mobilitas sosial. 4) keperluan integratif sosial yang merupakan keperluan tentang hubungan komunikasi sosial antar sesama baik dalam lingkungan keluarga, pendidikan, ataupun masyarakat. 5) keperluan entertain yang merupakan keperluan tentang pentingnya hiburan sebagai pelepas rasa stres yang dialami seseorang (Ichwani Siti Utami, 2018: 88-89).

Seorang individu tidak lepas dari individu lain, mereka saling terkait satu sama lain. Dapat dikatakan bahwa manusia itu tergolong sebagai makhluk sosial yang mana tidak dapat hidup sendirian tanpa adanya kejasama dengan individu lain (Toto Suryana, 2011: 127). Oleh karena itu kita sebagai makluk yang berakal seharusnya dapat mewarnai perbedaan dalam keragaman dengan penuh perdamaian, suka cita, dan ketulusan. Karena dalam keragaman kita mengetahui banyak perbedaan yang beraneka macam mulai dari perbedaan bahasa, budaya, etnis, warna kulit, agama, dan perbedaan pendapat. Perbedaan di ciptakan Tuhan untuk saling mengenal satu sama lain. Dari perkenalan akan muncul sikap saling memiliki dan saling mengasihi. Jika sikap-sikap tersebut sudah ada dalam diri individu, maka akan tercipta suatu perdamaian abadi yang terjalin erat. Perdamaian merupakan suatu kata dimana seseorang dapat hudup rukun, tentram, aman, dan nyaman dalam perbedaan. Karena perdamaian merupakan jiwa dalam kehidupan. Tugas utama dari seorang remaja adalah untuk mengabdikan diri dalam keberagaman yang ada di negara. Dan mengabdi pada negara salah 
satunya adalah dengan saling mengenal satu sama lain tidak ada tembok pembatas yang menghalanginya. Karena dari perkenalan akan memunculkan sikap saling memiliki, saling percaya, dan saling mengasihi antar sesama. Sehingga negara yang aman, damai, sejahtera, dan sentosa dapat terwujud.

\section{Simpulan}

Pluralisme merupakan suatu paham yang mengajarkan akan indahnya keberagaman baik dalam budaya, bahasa, etnis, ras, suku, dan agama. Pluralisme bukanlah suatu paham yang menyamaratakan ajaran dari semua agama. Akan tetapi pluralisme itu mengajrakan bahwa semua agama memiliki nilai-nilai kebenarannya sendiri-sendiri tergantung dari agamanya. Pluralisme itu menjunjung tinggi nilai-nilai kemanusiaan dengan menyebarkan perdamaian bukan ujaran kebencian. Pada hakikatnya semua agama mengajarkan umatnya akan cinta kasih. Pluralisme di Indonesia melahirkan hak-hak manusia untuk memilih agama menurut kepercayaannya masing-masing. Hal ini tercantum dalam Undang-Undang Dasar (UUD) Negara Republik Indonesia tahun 1945 Pasal 28 E ayat 1 yang menyatakan bahwa "Setiap orang bebas melakukan agama dan beribadah menurut agamanya, memilih pendidikan, dan pengajaran, memilih pekerjaan, memilih kewarganegaraan, memilih tempat tinggal di wilayah negara atau meninggalkannya, serta berhak kembali”. Hal ini sudah jelas bahwa setiap warga negara Indonesia diperbolehkan untuk memilih agama menurut kepercayaannya masing-masing tanpa adanya paksaan dari orang lain. Jadi setiap orang dilarang memaksakan kehendaknya untuk menyuruh orang lain supaya ikut memeluk kepercayaannya. Realitas pluralisme bangsa Indonesia tergolong dalam tingkat yang baik akan tetapi masih perlu untuk ditingkatkan lagi. Hal ini dikarenakan akhir-akhir ini banyak konflik-konflik yang terjadi baik itu konflik sosial, budaya, politk, bahkan agama. Konflikkonflik tersebut tidak seharusnya terjadi. Oleh karena itu kita sebagai pemuda bangsa harus mampu menciptakan negara yang aman damai sejahtera dalam keberagaman. Salah satu cara yang dapat kita lakukan adalah saling mengenal satu sama lain baik itu dari budaya, bahasa, etnis, warna kulit, ras, suku, dan agama. Karena dari perkenalan akan memunculkan sikap perdamaian.

\section{Daftar Pustaka}

Abdullah Amin M., (1993), “Keimanan Universal Di Tengah Pluralisme Budaya”, Ulumul Quran, No. 1.

Adib Muhammad, dan Nur Qomari, (2017), "Arus Baru Politik Islam: Pluralisme, Kontestasi, Dan Demokratisasi”, Maqashid, Vol.1 No.2. 
A'la Abd, (2002), Melampuai Dialog Agama, Jakarta: Kompas.

Arifin Miftah, dan Zainal Abidin, (2017), "Harmoni Dalam Perbedaan: Potret Relasi Muslim Dan Kristen Pada Masyarakat Pedesaan”, Fenomena, Vol. 16 No. 1.

Basyuni Maftuh M., (2008), Kebijakan Dan Strategi Kerukunan Umat Beragama, Jakarta: Badan Litbang Dan Diklat.

Eck L. Diana, (2002), Frontiers Of Faith: Religious Pluralism And Our Common Future, Stendhal Memorial Lecture, Stockholm.

Effendi Djohan, (1985), Dialog Antar Agama, Bisakah Melahirkan Kerukunan Agama Dan Tantangan Zaman, Jakarta: Lp3es.

Gunandi, dan Hartono, (200), Pendidikan Agama Konghucu Dan Budi Pekerti, Jakarta: Pusat Kurikulum Dan Perbukuan, Balitbang, Kemendikbud.

Hamid Lukman Asep, (2018), "Politik Identitas Agama Lokal Studi Tentang Aliran Kepercayaan Perjalanan Ciparay Bandung”, Al-Afkar, Vol. 2, No.1.

Hastuti Puji Ruri, dan Amika Wardana, (2017), "Multikulturalisme Dalam Pluralisme Agama (Islam, Buddha, Kristen) Untuk Menciptakan Integrasi Sosial”, Jurnal Pendidikan Sosiologi,

I Gusti Made Widya Sena, (2015), "Konsep Kosmologi Dalam Perspektif Agama Buddha”, Vidya Samhita Jurnal Penelitian, Vol. 1 No. 1.

Kartanegara Mulyadhi, (2007), Mengislamkan Nalar: Sebuah Respons Terhadap Modernitas (Jakarta: Erlangga.

Kasdi Abdurahman, (2012), "Pendidikan Multikultural Di Pesantren: Mambangun Kesadaran Keberagamaan Yang Inklusif”, Ad-Din, Vol. 4, No. 2.

Kristianto Aris, (2005) Pluralisme Agama Di Indonesia (Studi Tentang Tipologi Pluralisme Agama Nonindifferent Pada Keputusan Fatwa Mui Nomor 7 Tahun 2005).

Madjid Nurcholish, (1992), Islam Doktrin Dan Peradaban, Jakarta: Paramdina.

Misrawi Zuhairi, (2007), Al-Qur'an Kitab Toleransi, Jakarta: Firah.

Mohamad E. Nova, (2013), "Hukum Islam Dan Multikulturalis Pluralitas Di Indonesia”, AlHurriyah, Vol. 14, No. 2.

Nazmudin, (2017), "Kerukunan Dan Toleransi Antar Umat Beragama Dalam Membangun Keutuhan Negara Kesatuan Republik Indonesia (Nkri)", Journal Of Government And Civil Society, Volume 1, Nomor 1.

Rifa'i Afif, (2017), "Dealektika Pemikiran Dalam Dialog Antar Umat Beragama: Studi Kasus Forum Persaudaraan Umat Beriman (Fpub) Di. Yogyakarta”, Jurnal Pemberdayaan Masyarakat, Volume 1, Nomor 1.

Rijal Mohamad, (2018), "Pembinaaan Toleransi Antar Umat Beragama Perspektif Pendidikan Agama Islam Bagi Remaja Kota Kendari”, Al-Izzah, Volume 13, Nomor 2.

Riyanto, dan Halili, (2018), "Peranan Guru Pendidikan Pancasila Dan Kewarganegaraan Dalam Mengembangkan Sikap Toleran Antar Siswa Di Smp Negeri 1 Depok Sleman”, Jurnal Pndidikan Kewaraganegaraan Dan Hukum, Volume 7 No 6.

Rofiqoh Lani, dan Aris Suherman, (2017), "Peran Pendidikan Ilmu Pengetahun Sosialdalam Membentuk Karakter Pluralis Siswa Di Mts N 11 Cirebon”, Edueksos, Volume Vi, No 2. Rosyada Dede, (2006), "Materi Kurikulum, Pendekatan Dan Metode Pendidikan Agama Dalam Perspektif Multikultural”, Edukasi, Vol 4. No. 1. 
Setiawan Eko, (2017), “Konsep Teologi Pluralisme Gus Dur Dalam Meretas Keberagaman Di Indonesia”, Asketik, Vol. 1 No. 1.

Setiawan Sonie, dan Listyaningsih, "Peran Komunitas Young Interfaith Peacemaker Community Indonesia Di Surabaya Dalam Menumbuhkembangkan Sikap Toleransi Antar Umat Beragama”, Kajian Moral Dan Kewarganegaraan.Volume.06 Nomor 01, Tahun 2018, 137.

Suharyanto Agung, (2013), "Peranan Pendidikan Kewarganegaraan Dalam Membina Sikap Toleransi Antar Siswa”, Jurnal Ilmu Pemerintahan Dan Sosial Politik, Volume 1, No 2.

Sulaiman Dadang, (1995), Psikolog Remaja Dimensi-Dimensi Remaja Perkembangan, Bandung: Cv. Mandar Maju.

Suryana Toto, (2011), "Konsep dan Aktualisasi Kerukunan Antar Umat Beragama”, Jurnal Pendidikan Agama Islam, Vol. 9, No. 2.

Syah Darwyan, (2013) Pemahaman Surat-Surat Pendek Al-Qur'an Tentang Toleransi Dan Implikasinya Bagi Pengembangan Sikap Pluralisme, Analisis, Volume Xiii, Nomor 2.

Ulya Mifta, (2013), "Pendidikan Pluralis Pada Konteks Masyarakat Pesisir", Madania, Volume 3, No. 2.

Utami Siti Ichwani, (2018), "Pengaruh Persepsi Peserta Didik Mengenai Media Sosial Terhadap Sikap Toleransi”, Jurnal Pendidikan Kewarganegaraan, Vol. 5 No. 1.

Yunus Muhammad, (2017), "Implementasi Nilai-Nilai Toleransi Beragama Pada Pembelajaran Pendidikan Agama Islam (Studi Pada Smp Negeri 1 Amparita Kec. Tellu Limpoekab. Sidrap)", Al-Ishlah, Vol Xv , No.2.

Peraturan Menteri Pendidikan Nasional Tanggal 23 Mei Nomor 23 Tahun 2006.

English Dictionary, (2000), Oxford: Advanced Learner's Dictionary, Oxford University Press, Uk, 2000.

Mohamad Amin Madani, (2018) In Pictures: Aksi Damai Bela Kalimat Tauhid Https:/ / Republika.Co.Id/Berita/Inpicture/Nasional-Inpicture/18/10/26/Pb7gom283-Aksi-Damai-

Bela-Kalimat-Taubid.

Palupi Annisa Auliani,(2018) "Fakta Terkini Ledakan Bom Di Surabaya Sampai Pukul 10.12 Wib" Https://Nasional.Kompas.Com/Read/2018/05/13/10152071/Fakta-Terkini-Ledakan-BomDi-Surabaya-Sampai-Pukul-1012-Wib.

Yantina Debora, (2016) Kronologi Kasus Dugaan Penistaan Agama Https:/ / Tirto.Id/Kronologi-Kasus-Dugaan-Penistaan-Agama-B457,

Satya Widya: Jurnal Studi Agama

Volume 2 Nomor 1 Juni 2019 